\title{
Water quality status of an urban lake in the dry season from 2017 to 2020 (Situ Gintung, Banten Province, Indonesia)
}

\author{
Sinta Ramadhania Putri Maresi ${ }^{1 *}$, Tri Edhi Budhi Soesilo ${ }^{1}$, and Ami Aminah Meutia ${ }^{2}$ \\ ${ }^{1}$ School of Environmental Science, Universitas Indonesia, Jakarta, 10430, Indonesia. \\ ${ }^{2}$ Center for Southeast Asian Studies, Kyoto University, 46 Shimoadachi-cho, Yoshida Sakyo-ku, \\ Kyoto, 606-8501, Japan.
}

\begin{abstract}
Urban lakes are experiencing various kinds of problems because of the anthropocentrism of environmental management. This also happens in Situ Gintung, Indonesia. This lake is polluted by many pollutants from urban activities, such as the entry of domestic waste into waters due to anthropogenic activities and the amount of leftover food not consumed by fisheries. These problems can be solved by observing the water quality of Situ Gintung to provide information about parameters that have exceeded environmental quality standards and provide general information about the water quality in the dry season from 2017 to 2020 . The research is done using a purposive sampling method and determining water quality status with the STORET method based on the Indonesian standard with parameters less than ten. As a result, Situ Gintung water is neither classified as class I, II, III, and IV nor be utilized for consumption, recreation, fisheries, and irrigation because the quality status is mostly in the heavily polluted category. Furthermore, the three highest polluters from each class are BOD5, COD, and a total of Coliform.
\end{abstract}

\section{Introduction}

One of the development activities in urban areas which interferes with the environmental quality occurs in urban lakes. Based on survey results in the megacity of Jakarta (including Bogor, Depok, Tangerang, and Bekasi), lakes have some functions as a source of irrigation water $(44 \%)$, water reservoir $(31 \%)$, flood control $(10 \%)$, fisheries $(8 \%)$, nature tourism $(3 \%)$, and others (4\%) [1]. Nevertheless, urban lakes currently experience various kinds of problems, including physical and ecological problems, which lead to a decrease in their water quality [2]. This problem is probably caused by environmental management that follows anthropocentrism, which sees the problem only from human interests so that other components of the ecosystem are neglected [3]. This undoubtedly contrasts with the concept of environmental science, which views every element in the environment must be diverse, sustainable, harmonious, mutually influencing, and contracting with one another.

\footnotetext{
* Corresponding author: sintamaresi@ gmail.com
} 
Problems in urban lakes also occur in Situ Gintung, South Tangerang City, Banten Province, such as the entry of domestic waste into waters due to anthropogenic activities [4][6] and the amount of leftover food from fisheries activities [4]. Originally, Situ Gintung is part of the Pesanggrahan River Basin in the Banten Province and DKI Jakarta, Indonesia. In this case, Situ Gintung belongs to the authority of Ciliwung and Cisadane Rivers Area Main Station (BBWSCC) [7]. Since 1970, Situ Gintung has changed its function to become a water catchment area and tourist destination.

A swimming pool, an outbound place, and restaurants were built to support the tourism function [8]. This also has been supported by South Tangerang City Regulation Number 15/2011 concerning Spatial Planning for the South Tangerang City in 2011-2031, which explains that Situ Gintung is directed to developing natural tourism recreation.

There are some houses, offices, educational institutions, restaurants, and recreation areas built in the upstream area of Situ Gintung. At the same time, Situ Gintung downstream has been transformed from a watershed area to a residential area and business place in the period 1980-2010 [9]. However, these added functions were not balanced with its lake management. Finally, on March 27, 2009, Situ Gintung collapsed on the dam, which became a water barrier with the width and the height around $30 \mathrm{~m}$ and $6 \mathrm{~m}$, respectively. Millions of cubic meters of water flooded the settlements in the northern part of the area (Ministry of Public Works and Housing; Indonesian Architects Association, 2009) and caused more than a hundred fatalities and injured in this disaster [10].

In this case, the Situ Gintung function additions do not consider the balance factor between humans and the environment yet. Furthermore, this does not follow the principle of environmental management from Commoner in 1971, i.e., humans' substances do not interfere with any biogeochemical processes on earth [11]. The relationship is that the Situ Gintung management effort, including its developments, must be ensured not to disturb the environmental balance.

To maintain the balance of the environment, especially in urban lakes, monitoring of periodic water quality, based on physical, chemical, or biological parameters, is required to provide the necessary data to protect the environment from various contaminants. These contaminants possibly come from anthropogenic activities [12][13], including household activities (bathing, cooking, and washing), littering into rivers, and disposing of wastewater from households [2], [12], [14].

Based on the background descriptions, observation of the urban lake's water quality is essential to provide information about parameters that have exceeded environmental quality standards and provide general information about the water quality status in the last four years in Situ Gintung. The observation will be held in the dry season to minimize the influence of rainfall in the water quality data. So, hopefully, the data will show the exact condition of Situ Gintung water.

\section{Method}

\subsection{Research area}

This research applies a quantitative method and approach to obtain data in values from measured variables. Then, the research is finished by using a purposive sampling method. This study uses two kinds of data of Situ Gintung, namely primary data and secondary data. Primary data is obtained from direct water sampling in August 2020. Sampling is carried out in the dry season when the rainfall intensity is less than $50 \mathrm{~mm}$ [15]. Water samples are collected from three sampling points at a depth of 2 to 5 meters from the water surface at S1 (inlet 1) S: $06^{\circ} 18^{\prime} 39^{\prime \prime} \mathrm{E}: 106^{\circ} 45^{\prime} 53^{\prime \prime}, \mathrm{S} 2$ (inlet 2) S: $06^{\circ} 18^{\prime} 39^{\prime \prime} \mathrm{E}: 106^{\circ} 45^{\prime} 38^{\prime \prime}$, and S3 (outlet) 
S: $06^{\circ} 18^{\prime} 05^{\prime \prime}$ E: $106^{\circ} 45^{\prime} 47^{\prime \prime}$ (the map of the research location is presented in Figure 1). Meanwhile, the secondary data are also taken when the rainfall is low, less than $50 \mathrm{~mm}$ [15] in 2017 (August), 2018 (August), and 2019 (July) through BBWSCC, Jakarta.

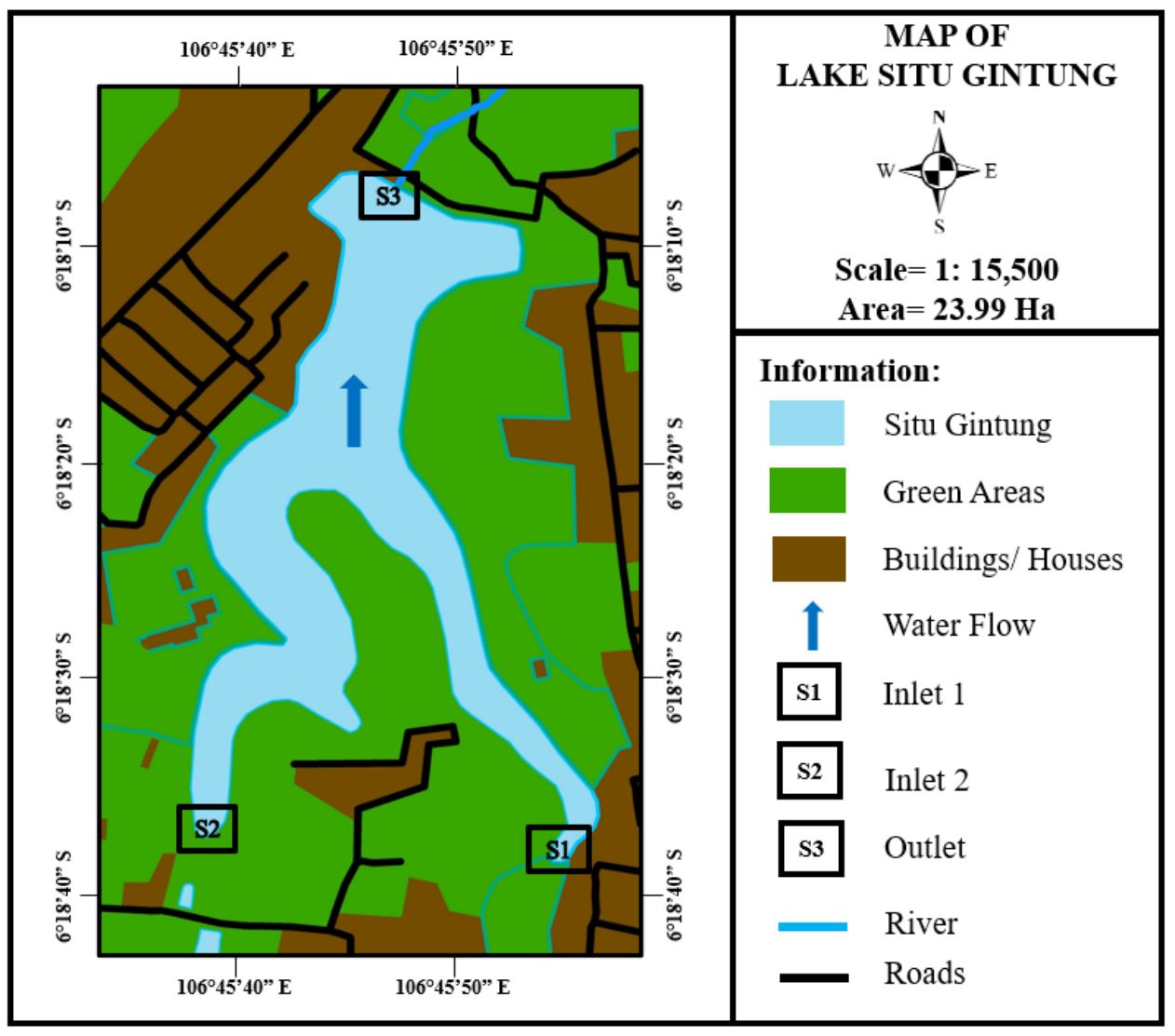

Fig 1. Research Location Map (Source: The Geospatial Information Agency (BIG), Indonesia)

\subsection{Water quality analysis}

The surface water sampling method is certified under the Indonesian National Standard (SNI) Number 6989.57-2008. The quality of water samples is measured through 7 parameters, which are chosen because of the readiness of the data from chemical (biological oxygen demand/ $\mathrm{BOD}_{5}$, chemical oxygen demand/COD, dissolved oxygen/DO, a total of phosphorus $/ \mathrm{PO}_{4}$, and ammonium as $\mathrm{NH}_{3}-\mathrm{N}$ ), physical (temperature), and biological (a total of Coliform) condition.

Table 1. Analysis methods of the observed parameters

\begin{tabular}{|c|c|c|c|c|c|c|c|}
\hline \multirow[b]{2}{*}{ No. } & \multirow[b]{2}{*}{ Parameters } & \multirow[b]{2}{*}{ Units } & \multirow[b]{2}{*}{ Methods } & \multicolumn{4}{|c|}{ Quality Standards } \\
\hline & & & & $\begin{array}{c}\text { Class } \\
\text { I }\end{array}$ & $\begin{array}{c}\text { Class } \\
\text { II }\end{array}$ & $\begin{array}{c}\text { Class } \\
\text { III }\end{array}$ & $\begin{array}{c}\text { Class } \\
\text { IV }\end{array}$ \\
\hline 1. & Temperature & ${ }^{0} \mathrm{C}$ & $\begin{array}{l}\text { SNI 06-6989.23- } \\
2005\end{array}$ & \multicolumn{3}{|c|}{$\begin{array}{l}\text { Deviation } \\
3\end{array}$} & $\begin{array}{c}\text { Deviation } \\
5 \\
\end{array}$ \\
\hline 2. & $\mathrm{BOD}_{5}$ & $\mathrm{mg} / \mathrm{L}$ & $\begin{array}{l}\text { SNI 6989.72- } \\
2009\end{array}$ & 2 & 3 & 6 & 12 \\
\hline
\end{tabular}




\begin{tabular}{|c|l|c|l|c|c|c|c|}
\hline 3. & COD & $\mathrm{mg} / \mathrm{L}$ & SNI 6989.2-2009 & 10 & 25 & 50 & 100 \\
\hline 4. & $\mathrm{DO}$ & $\mathrm{mg} / \mathrm{L}$ & $\begin{array}{l}\text { SNI 06-6989.14- } \\
2004\end{array}$ & 6 & 4 & 3 & 0 \\
\hline 5. & $\mathrm{PO}_{4}$ & $\mathrm{mg} / \mathrm{L}$ & $\begin{array}{l}\text { APHA Ed.22nd } \\
4500-\mathrm{P} . \text { B\&E- } \\
2012\end{array}$ & 0.2 & 0.2 & 1 & 5 \\
\hline 6. & $\mathrm{NH}_{3}-\mathrm{N}$ & $\mathrm{mg} / \mathrm{L}$ & $\begin{array}{l}\text { SNI 06-6989.30- } \\
2005\end{array}$ & 0.5 & 0.5 & 0.02 & 0.02 \\
\hline 7. & $\begin{array}{l}\text { a Total of } \\
\text { Coliform }\end{array}$ & $\begin{array}{l}\text { MPN/ } \\
100 \mathrm{ml}\end{array}$ & $\begin{array}{l}\text { APHA Ed.22nd } \\
\text { 9221 } \\
\text { B-2012 }\end{array}$ & 1,000 & 5,000 & 10,000 & 10,000 \\
\hline
\end{tabular}

The data measurements will be categorized based on classes or the rates of water quality, which are considered adequate for use in specific designations. These classes, as shown in Table 1, is from the Indonesian Government Regulation Number 82/2001 about Water Quality Management and Water Pollution. Then, the obtained data is analyzed, evaluated, and concluded with the support of relevant literature. In the next stage, the water quality results in all parameters are calculated through the STORET method in the standard of environmental quality based on The Ministry of Environment Regulation Republic of Indonesia Number 115/2003 [16]. This method's usage is based on its ability to integrate many parameters so that the water quality description will be more comprehensive without any limitation among the parameters.

There are some steps to determine the water quality status using the STORET method [16]. Firstly, the periodic data of water quality are collected primarily (2020) or secondarily $(2017,2018$, and 2019) and formed as time-series data. These measured data (shown in Table 4 and Table 5) from every parameter are compared to the quality standard under the water classes (described in Table 1). In this stage, the comparison is only focused on the maximum ( $\max$ ), minimum ( $\mathrm{min}$ ), and average (avg) results. If the compared data (max, min, and avg) fulfill the quality standards in each class, which means that these data are less than or equal to the standards, the score 0 is given as a STORET method result. However, if the data do not fulfill the standards, the scores from Table 2 are provided as a result. For the exception, the DO data will fulfill the standards when the measured data are more than or equal to the water quality standards.

Table 2. The value of water quality parameters based on the STORET method

\begin{tabular}{|c|c|c|c|c|}
\hline \multirow{2}{*}{ Sample Quantity } & \multirow{2}{*}{ Scores } & \multicolumn{3}{|c|}{ Parameters } \\
\cline { 3 - 5 } & & Physics & Chemistry & Biology \\
\hline \multirow{3}{*}{ Less than 10 parameters } & Max & -1 & -2 & -3 \\
\cline { 2 - 5 } & Min & -1 & -2 & -3 \\
\cline { 2 - 5 } & Avg & -3 & -6 & -9 \\
\hline \multicolumn{2}{|c|}{ The total score for each parameter } & -5 & -10 & -15 \\
\hline
\end{tabular}

Finally, the calculated data should be classified through US-EPA (United StateEnvironmental Protection Agency) water quality standards, as described in Table 3.

Table 3. The water quality classification based on US-EPA

\begin{tabular}{|c|c|}
\hline Total Scores & Pollution levels \\
\hline 0 & Fulfilled Quality Standard \\
\hline from -10 to -1 & Lightly Contaminated \\
\hline
\end{tabular}




\begin{tabular}{|c|c|}
\hline from -30 to -11 & Moderately Polluted \\
\hline less than -30 & Heavily Polluted \\
\hline
\end{tabular}

\section{Results and discussion}

The monitoring of water quality has 3 (three) primary objectives: understanding the water quality based on science parameters, comparing water quality values with the quality standards from Indonesian Government Regulation Number 82/2001 (Appendix 1), and assessing the suitability of water for particular interests [17].

This decree classifies water quality standards according to their designation into 4 (four) classes as follows:

1. First-category, water can be drunk from the raw condition;

2. Second-category, water can be utilized for recreation, fisheries, livestock, and irrigating crops;

3. Third-category, water can be purposed for the fisheries, animal husbandry, and irrigating crops; and

4. Fourth-category, water can be used to irrigate crops.

The water quality condition of Situ Gintung based on data from 3 points of observation, namely inlet 1 (S1), inlet 2 (S2), and outlet (S3) (Figure 1), is shown in Table 4 and Table 5.

Table 4. Test Results of Water Quality in Situ Gintung Year 2017-2018

\begin{tabular}{|c|c|c|c|c|c|c|c|c|c|c|}
\hline \multirow{2}{*}{ No. } & \multirow{2}{*}{ Parameters } & \multirow{2}{*}{ Unit } & \multicolumn{4}{|c|}{$2017^{*}$} & \multicolumn{4}{|c|}{$2018^{*}$} \\
\hline & & & S1 & S2 & S3 & Avg & S1 & S2 & S3 & Avg \\
\hline 1. & $\begin{array}{l}\text { Temperatur } \\
\mathrm{e}\end{array}$ & ${ }^{\circ} \mathrm{C}$ & 30 & 30 & 29 & 29.67 & 29 & 29 & 30 & 29.33 \\
\hline 2. & $\mathrm{BOD}_{5}$ & $\mathrm{mg} / \mathrm{L}$ & 31.0 & 37.0 & 19.0 & 29 & 46 & 19 & 22 & 29 \\
\hline 3. & COD & $\mathrm{mg} / \mathrm{L}$ & 105.0 & 132.0 & 83.0 & 106.67 & 154 & 77 & 77 & 102.67 \\
\hline 4. & DO & $\mathrm{mg} / \mathrm{L}$ & 3.7 & 1.0 & 3.2 & 2.63 & 0.5 & 1 & 1 & 0.83 \\
\hline 5. & $\mathrm{PO}_{4}$ & $\mathrm{mg} / \mathrm{L}$ & 1.0 & 2.0 & 0.3 & 1.1 & 2 & 1 & 0.23 & 1.08 \\
\hline 6. & $\mathrm{NH}_{3}-\mathrm{N}$ & $\mathrm{mg} / \mathrm{L}$ & 0.4 & 0.8 & 0.04 & 0.41 & $<0.01$ & 0.01 & $<0.01$ & 0.01 \\
\hline 7. & $\begin{array}{l}\text { a Total of } \\
\text { Coliform }\end{array}$ & $\begin{array}{l}\text { MPN/ } \\
100 \mathrm{ml}\end{array}$ & 54,000 & 84,000 & 21,000 & 53,000 & 38,000 & 21,000 & 11,000 & 23,333 \\
\hline
\end{tabular}

Table 5. Test Results of Water Quality in Situ Gintung Year 2019-2020

\begin{tabular}{|c|l|c|c|c|c|c|c|c|c|c|}
\hline \multirow{2}{*}{ No. } & \multirow{2}{*}{ Parameters } & \multirow{2}{*}{ Unit } & \multicolumn{6}{|c|}{$2019^{*}$} & \multicolumn{4}{|c|}{$2020^{* *}$} \\
\cline { 5 - 11 } & & & $\mathrm{S} 1$ & $\mathrm{~S} 2$ & $\mathrm{~S} 3$ & $\mathrm{Avg}$ & $\mathrm{S} 1$ & $\mathrm{~S} 2$ & $\mathrm{~S} 3$ & Avg \\
\hline 2. & Temperature & ${ }^{\circ} \mathrm{C}$ & 30 & 31 & 31 & 30.67 & 30.1 & 29.3 & 29.1 & 29.5 \\
\hline 3. & $\mathrm{BOD} 5$ & $\mathrm{mg} / \mathrm{L}$ & 20 & 8 & 10 & 12.67 & 26 & 28 & 13 & 22.33 \\
\hline 4. & $\mathrm{DO}$ & $\mathrm{mg} / \mathrm{L}$ & 88 & 37 & 45 & 56.67 & 87.9 & 97.5 & 43.2 & 76.2 \\
\hline 5. & $\mathrm{PO}_{4}$ & $\mathrm{mg} / \mathrm{L}$ & 3.4 & 3.3 & 3.2 & 3.3 & 4.5 & 6 & 5.8 & 5.43 \\
\hline 6. & $\mathrm{NH}_{3}-\mathrm{N}$ & $\mathrm{mg} / \mathrm{L}$ & 1.6 & 2.4 & 1.5 & 1.83 & 0.24 & 1.46 & 0.31 & 0.67 \\
\hline
\end{tabular}




\begin{tabular}{|l|l|l|l|l|l|l|l|l|l|l|}
7. & $\begin{array}{l}\text { a Total of } \\
\text { Coliform }\end{array}$ & $\begin{array}{l}\text { MPN/ } \\
100 \mathrm{ml}\end{array}$ & 21,000 & 27,000 & 24,000 & 24,000 & 2,090 & 9,650 & 510 & 4,083 \\
\hline
\end{tabular}

Source: * Secondary data from BBWSCC

** Primary Data, August 2020, taken by an accredited laboratory

The data from Table 4 and Table 5 is compared to Table 1 based on the STORET Method, and the results are presented in Table 6 and Table 7.

Table 6. Test Result based on the STORET Method (Class I and Class II)

\begin{tabular}{|c|c|c|c|c|c|c|c|c|c|c|}
\hline \multirow{2}{*}{ No. } & \multirow{2}{*}{ Parameters } & \multirow{2}{*}{ Unit } & \multicolumn{4}{|c|}{ Class I } & \multicolumn{4}{|c|}{ Class II } \\
\hline & & & 2017 & 2018 & 2019 & 2020 & 2017 & 2018 & 2019 & 2020 \\
\hline 1. & Temperature & ${ }^{\circ} \mathrm{C}$ & 0 & 0 & 0 & 0 & 0 & 0 & 0 & 0 \\
\hline 2. & $\mathrm{BOD}_{5}$ & $\mathrm{mg} / \mathrm{L}$ & -10 & -10 & -10 & -10 & -10 & -10 & -10 & -10 \\
\hline 3. & COD & $\mathrm{mg} / \mathrm{L}$ & -10 & -10 & -10 & -10 & -10 & -10 & -10 & -10 \\
\hline 4. & DO & $\mathrm{mg} / \mathrm{L}$ & -10 & -10 & -10 & -8 & 0 & 0 & 0 & -10 \\
\hline 5. & $\mathrm{PO}_{4}$ & $\mathrm{mg} / \mathrm{L}$ & -10 & -10 & -10 & -10 & -10 & -10 & -10 & -10 \\
\hline 6. & $\mathrm{NH}_{3}-\mathrm{N}$ & $\mathrm{mg} / \mathrm{L}$ & -2 & 0 & 0 & -10 & -2 & 0 & 0 & -10 \\
\hline 7. & $\begin{array}{l}\text { a Total of } \\
\text { Coliform }\end{array}$ & $\begin{array}{l}\text { MPN/ } \\
100 \mathrm{ml}\end{array}$ & -15 & -15 & -15 & -12 & -15 & -15 & -15 & -3 \\
\hline \multicolumn{3}{|c|}{ Total Score } & -57 & -55 & -55 & -60 & -47 & -45 & -45 & -53 \\
\hline
\end{tabular}

Table 7. Test Result based on STORET Method (Class III and Class IV)

\begin{tabular}{|c|c|c|c|c|c|c|c|c|c|c|}
\hline \multirow{2}{*}{ No. } & \multirow{2}{*}{ Parameters } & \multirow{2}{*}{ Unit } & \multicolumn{4}{|c|}{ Class III } & \multicolumn{4}{|c|}{ Class IV } \\
\hline & & & 2017 & 2018 & 2019 & 2020 & 2017 & 2018 & 2019 & 2020 \\
\hline 1. & Temperature & ${ }^{\circ} \mathrm{C}$ & 0 & 0 & 0 & 0 & 0 & 0 & 0 & 0 \\
\hline 2. & $\mathrm{BOD}_{5}$ & $\mathrm{mg} / \mathrm{L}$ & -10 & -10 & -10 & -10 & -10 & -10 & -8 & -10 \\
\hline 3. & COD & $\mathrm{mg} / \mathrm{L}$ & -10 & -10 & -8 & -8 & -8 & -8 & 0 & 0 \\
\hline 4. & DO & $\mathrm{mg} / \mathrm{L}$ & -2 & 0 & -10 & -10 & -10 & -10 & -10 & -10 \\
\hline 5. & $\mathrm{PO}_{4}$ & $\mathrm{mg} / \mathrm{L}$ & -8 & -8 & -10 & -2 & 0 & 0 & 0 & 0 \\
\hline 6. & $\mathrm{NH}_{3}-\mathrm{N}$ & $\mathrm{mg} / \mathrm{L}$ & -10 & 0 & -8 & -10 & -10 & 0 & -8 & -10 \\
\hline 7. & $\begin{array}{l}\text { a Total of } \\
\text { Coliform }\end{array}$ & $\begin{array}{l}\mathrm{MPN} / \\
100 \mathrm{ml}\end{array}$ & -15 & -15 & -15 & 0 & -15 & -15 & -15 & 0 \\
\hline \multicolumn{3}{|c|}{ Total Score } & -55 & -43 & -61 & -40 & -53 & -43 & -41 & -30 \\
\hline
\end{tabular}

In general, based on results explained in Table 6 and Table 7, the quality of Situ Gintung water is mostly categorized as heavily polluted in the dry season in the last four years. Furthermore, the water cannot be classified into one of the four explained standards. This means that Situ Gintung water is not adequate for consumption, recreation, fisheries, and irrigation. This is also supported by research from the United Nations University, which is shown that, since 2010, all water levels crossing Jakarta and its surroundings have been categorized as heavily polluted. The cause of pollutants comes from gray water such as households, commercial buildings, industrial waste, pesticide and fertilizer waste from agricultural land, solid waste, and sewage from overflowing or leaking septic tanks [18].

During the period, the water quality of Situ Gintung from Class I standard is in the heavily polluted category with values from -60 to -55 . This means that the water is inconsumable for drinking and bathing, cooking, and washing. Some most significant parameters which reveal this pollution are $\mathrm{BOD}_{5}, \mathrm{COD}, \mathrm{DO}, \mathrm{PO}_{4}$, and a total of Coliform. This condition also happens in double standard (Class II). With the same significant parameters, the values for the water quality of Situ Gintung based on Class II are from -53 to -45 . These values are less than Class 
I but still in the same category (heavily polluted). As a result, the lake is incapable of recreation activities.

In Class III, the STORET method's parameters are still less than -30 from -55 in 2017 to -40 in 2020 . Because of this heavily polluted condition, the water cannot be used for fisheries and livestock. The most vital parameters which explain the pollution are $\mathrm{BOD}_{5}, \mathrm{COD}$, and a total of Coliform.

A hope to utilize the water lake for irrigation is also gone due to Class IV calculation results. This can be seen in Table 7 that the water is still categorized as heavily polluted in 2017,2018 , and 2019 with score $-53,-43,-41$, respectively. The parameters dominated in the scores are $\mathrm{BOD}_{5}, \mathrm{COD}$, and a total of Coliform. However, in 2020, the water quality is improved to be moderately polluted with a score of -30 . Though this is still not an excellent score to function the water for irrigation purposes, this improved score undoubtedly should be a good sign for the society to rehabilitate the quality of Situ Gintung water.

From the above explanation, the largest contributors to the pollution in every class in 2017-2020 are $\mathrm{BOD}_{5}, \mathrm{COD}$, and a total of Coliform. $\mathrm{BOD}_{5}$ and $\mathrm{COD}$, which represent the water quality of sewage, indirectly indicate organic matter in the water [19]. Overall, the high values of $\mathrm{BOD}_{5}$ and $\mathrm{COD}$, which contain organic matter, is a potential problem of water bodies pollution, including lakes in urban areas, so that the degradation process requires large amounts of oxygen [20]. In this condition, The US-EPA requires wastewater treatment plants to carry $\mathrm{BOD}_{5}$ within quality limits before discharging treated wastewater into waters, so measuring $\mathrm{BOD}_{5}$ or $\mathrm{COD}$ in treated wastewater is an essential part of the monitoring process. $\mathrm{BOD}_{5}$ also describes the level of water pollution by organic waste, so the higher the $\mathrm{BOD}_{5}$ value, the greater the level of pollution [21].

On the other hand, the $\mathrm{BOD}_{5}$ examination is needed to determine the pollution load due to wastewater from residents or industries. If the wastewater, which is contaminated by organic substances, comes into the lake, the bacteria can use up dissolved oxygen in the lake's oxidation process. This condition can lead to death in fisheries, and the condition becomes anaerobic and creates a bad smell in the water [22]. Meanwhile, according to the provisions of the World Health Organization (WHO) and the American Public Health Association (APHA), water quality is also determined by the presence and number of bacteria, including Coliform [21] [23]. This means that if Coliform or other kinds of aquatic bacteria contaminate the human body, these bacteria mostly will cause diseases for the society, especially the diseases from waterborne, which have plagued the human population for centuries [24]. Symptoms of illness that may arise from these pathogens include diarrhea, fever, stomach cramps, and vomiting [23]. If the known level of Coliform contamination is high, other pathogenic bacteria's contamination risk is also high. Then, this indicates that the water is highly polluted [21].

Besides, lake water quality in urban areas is also influenced by meteorological factors, including deposition, wind speed, temperature, and sunshine duration [25]-[27]. Several studies have shown that summer causes the release of nutrients, and heavy rainfall will cause non-point source pollution, which can lead to the enrichment of nutrient and the lakes eutrophication [25], [28], [29]. During the rainy season, the intensity of rainfall and runoff affects accumulated contaminants' dilution effect in waters [25]. Finally, this indicates that pollutant concentrations in surface water are mostly higher during the dry season than the rainy season.

Moreover, from the description of water quality influences, there is an indication that water quality scores are affected by several community activities, such as housing, the laundry industry, and garbage disposal. Ultimately, the water is contaminated seriously and cannot be used for human necessities. This is also worsened by the dry season because the water nutrient is limited. On the other hand, as a strategic area, Situ Gintung has to support the function and carrying capacity of the environment. Furthermore, based on the Regulation 
of South Tangerang City Number 15/2011, Situ Gintung should be handled to develop recreation and nature tourism activities. However, the explained water quality fact does not strengthen the idea of tourism activities in the lake. So, if the authorities stay with this notion, they prioritize the restoration of Situ Gintung water quality primarily.

\section{Conclusion}

Situ Gintung water conditions in the dry season in 2017-2020 based on Indonesian standards cannot be classified into class I, II, III, or IV, and cannot be utilized for consumption, recreation, fisheries, and irrigation. This is because the water status is mostly in the heavily polluted category. Also, the largest contributors that pollute the lake in each class are $\mathrm{BOD}_{5}$, COD, and Coliform. However, this research only uses data from seven parameters in three points a year and only in the dry season. So, suppose the next research can be supported by many parameters in many sampling points in the two main seasons (dry and wet) from a more extended period. In that case, it will show better data and results in the water quality of the lake. On the other hand, if the government still plans to build Situ Gintung as a recreation area, they must first prioritize the water quality restoration of the lake. Then, they can shape the lake as a tourist destination and still maintain its water quality.

\section{Acknowledgements}

This research is funded by Universitas Indonesia through Grant of International Publication (PUTI) Social and Humanities with contract number NKB2571/UN2.RST/HKP.05.00/2020. The authors then further express gratitude to South Tangerang Agency for National Unity, Politics and Community Protection (Kesbangpol), BBWSCC, Mitralab Buana Company, BIG, and BMKG for supporting data for this research.

\section{References}

1. Ministry of Environment and Forestry, Strategy and Action Plan for Situ Preservation of Jabodetabek Area (Ministry of Environment and Forestry, Jakarta, 2007)

2. C. Henny and A. A. Meutia, Urban lakes in megacity Jakarta: risk and management plan for future sustainability, Proc. Env. Sci. 20 (2014) https://doi.org/ 10.1016/j.proenv.2014.03.088

3. O. Soemarwoto, Environmental Ecology and Development (Bumi Aksara Company, Jakarta, 2005)

4. S. Bahri, F. Ramadhan, and I. Reihannisa, Water Quality Situ Gintung, South Tangerang, Biog. J. Ilm. Biol. 3, 1 (2015) https://doi.org/10.24252/bio.v3i1.561

5. Y. Mardiansyah, A. F. Rijaludin, and F. Ramadhan, Water quality index and phytoplankton period of Ramadan in Situ Gintung, South Tangerang, Banten, Biotropic J. Trop. Biol. 3, 2 (2019) https://doi.org/10.29080/biotropic.2019.3.2.105-121

6. A. Widyana and M. Widyastuti, Study of water quality in the village of East Ciputat, South Tangerang City, J. Bumi Indonesia. 2, 4 (2013) http://lib.geo.ugm.ac.id/ojs/index.php/jbi/article/view/556

7. M. R. Nugroho, Critical Analysis of the Situ Gintung Ciputat Watershed (DAS) South Tangerang (State Islamic University, Jakarta, 2010)

8. Ministry of Public Works and Public Housing and the Indonesian Architects Association, Terms of Reference Situ Gintung Area Structuring Ideas Contest, Paper Working, Jakarta (2009) 
9. S. M. Adi, Center for Organic Agriculture and Inland Fisheries in the Downstream Area of Situ Gintung, Tangerang, Banten, (Universitas Indonesia, Jakarta, 2010)

10. B. Harsoyo, The collapse of the Situ Gintung embankment (March 27, 2009) was not due to extreme rainfall, J. Sains Teknol. Modif. Cuaca. 11, 1 (2010) https://doi.org/10.29122/jstmc.v11i1.2176

11. F. Obeng-Odoom, Enclosing the urban commons: crises for the Commons and Commoners, Sustain. Cities Soc. 40 (2018) https://doi.org/10.1016/j.scs.2018.01.001

12. R. Bhateria and D. Jain, Water quality assessment of lake water: a review, Sustain. Water Resour. Manag. 2, 2 (2016) https://doi.org/10.1007/s40899-015-0014-7

13. R. Altenburger et al., Future water quality monitoring: improving the balance between exposure and toxicity assessments of real-world pollutant mixtures, Environ. Sci. Eur. 31, 1 (2019) https://doi.org/10.1186/s12302-019-0193-1

14. N. V. Sidabutar, I. Namara, D. M. Hartono, and T. E. B. Soesilo, The effect of anthropogenic activities to the decrease of water quality, in International Conference on Environment and Industrial Innovation 24-26 April 2017, Kuala Lumpur, Malaysia 67, 1 (2017) https://doi.org/10.1088/1755-1315/67/1/012034

15. South Tangerang Climatology Station, BMKG Bulletin Banten and DKI Jakarta Provinces, (BMKG, Jakarta, 2020)

16. Ministry of Environment, Decree of the State Minister of Environment Number 115 concerning Guidelines for Determining Water Quality Status, (2003)

http://ciptakarya.pu.go.id/plp/index.php/v2/kategori_peraturan/5/20

17. H. Effendi, Study of Water Quality (For Management of Water Resources and Environment), (Kanisius Company, Yogyakarta, 2003)

18. Apip, S. A. H. Sagala, and L. Pingping, Overview of Jakarta Water-Related Environmental Challenges, Water and Urban Initiative Working Paper, in United Nations University Institute for the Advanced Study of Sustainability, 4 (2015)

19. J. Hur, B. M. Lee, T. H. Lee, and D. H. Park, Estimation of biological oxygen demand and chemical oxygen demand for combined sewer systems using synchronous fluorescence spectra, Sensors. 10, 4 (2010) https://doi.org/10.3390/s100402460

20. A. M. Al-Sulaiman and B. H. Khudair, Correlation between $\mathrm{BOD}_{5}$ and COD for AlDiwaniyah wastewater treatment plants to obtain the biodigrability indices, J. Biotechnol. 15, 2 (2018) http://www.pjbt.org/uploads/2018/Vol-5/PJBT-VOL-15-NO2-OF-YEAR-2018\%20(24).pdf

21. P. L. Dangi, B. K. Sharma, and B. Uppadhyay, BOD, total and faecal coliforms bacterial status of Lake Pichhola, Udaipur, Rajasthan, Int. J. Fish. Aquat. Stud. 5, 3 (2017) https://www.fisheriesjournal.com/archives/2017/vol5issue3/PartC/5-3-25-778.pdf

22. G. Alaerts and S. S. Santika, Water Research Methods. (Usaha National Company, Surabaya, 1987)

23. I. W. S. Warpala, N. L. P. M. Widiyanti, I. A. Suryanti, and I. W. S. Wibawa, Diversity genera of coliforms bacteria in Buyan Lake, Adv. in Soc. Sc. Ed. and Hum. Res. 394 (2020) https://doi.org/10.2991/assehr.k.200115.005

24. G. H. Donovan, Y. L. Michael, D. Gatziolis, and R. W. Hoyer, The relationship between the natural environment and individual-level academic performance in Portland, Oregon, Environ. (2018) https://doi.org/10.1177/0013916518796885

25. X. Xia, Impacts of meteorological variations on urban lake water quality: A sensitivity analysis for 12 urban lakes with different trophic states, Aquat. Sci. 76, 3 (2014) https://doi.org/10.1007/s00027-014-0339-6

26. X. Fan, B. Cui, K. Zhang, Z. Zhang, and H. Shao, Water quality management based on division of dry and wet seasons in Pearl River Delta, China, Clean - Soil, Air, Water. 40, 4 (2012) https://doi.org/10.1002/clen.201100123 
27. W. J. Mitsch and M. E. Hernandez, Landscape and climate change threats to wetlands of North and Central landscape and climate change threats to wetlands of North and Central America, Aquat. Sci. 75 (2013) https://doi.org/10.1007/s00027-012-0262-7

28. S. Kosten et al., Warmer climates boost cyanobacterial dominance in shallow lakes, Glob. Chang. Biol. 18, 1 (2012) https://doi.org/10.1111/j.1365-2486.2011.02488.x

29. L. N. D. D. Domis et al., Plankton dynamics under different climatic conditions in space and time, Freshw. Biol. 58, 3 (2013) https://doi.org/10.1111/fwb.12053 